\title{
WERYFIKACJA MOŻLIWOŚCI WYKORZYSTANIA NIEPARAMETRYCZNEGO TESTU NIEZALEŻNOŚCI DO ANALIZY POSTRZEGANIA WYBRANYCH ELEMENTÓW KOMUNIKACJI WIZUALNEJ OPAKOWAŃ
}

\begin{abstract}
Opakowanie to nowoczesne narzędzie zintegrowanego marketingu i jeden $\mathrm{Z}$ ważniejszych atrybutów produktu wpływających na preferencje zakupowe konsumentów. Opakowanie ma za zadanie stworzyć pożądany wizerunek produktu, który będzie wzbudzał zaufanie oraz przekona do zakupu. Wpływa ono na identyfikowalność danego wyrobu z marką, różnicuje te same artykuły kilku producentów, wspomaga komunikację, a także edukuje. Jako nośnik komunikacji opakowanie pełni funkcję elementu identyfikującego dany produkt $\mathrm{z}$ marką. Stąd współcześnie opakowanie traktowane jest jako narzędzie skutecznej komunikacji z potencjalnym konsumentem. Opakowanie traktowane jest ponadto jako istotny nośnik zakodowanych komunikatów rynkowych. Spójny system wizualny opakowania może być jednym z ważniejszych elementów całościowej identyfikacji, który bezpośrednio przekłada się na sposób postrzegania produktu przez konsumenta i w efekcie może mieć decydujący wpływ na jego wybór. Poprzez oryginalność formy i treści przekazu można skutecznie oddziaływać na potencjalnego odbiorcę. Celem pracy jest analiza wybranych elementów komunikacji wizualnej opakowań z wykorzystaniem metod badań okulograficznych. Z uwagi na pomiarowy i fizjologiczny charakter badania wykorzystującego eyetracker Tobii X2-30, bazującego na pomiarze pracy narządu wzroku, uzyskano możliwość otrzymania reprezentatywne danych ilościowych. Ponadto otrzymano również mierzalny materiał jakościowy, będący punktem wyjścia do innego typu badań np. deklaratywnych. Eksploracja wyników badań okulograficznych umożliwi wskazanie najbardziej efektywnych elementów komunikacji wizualnej opakowań. Natomiast wykorzystanie testu $\chi^{2}$ pozwoli na określenie zależności postrzegania graficznych i typograficznych elementów komunikacji opakowań od grup wiekowych badanych.

Słowa kluczowe: komunikacja wizualna opakowań, eye-tracking, nieparametryczny test niezależności.
\end{abstract}

\section{WPROWADZENIE}

Rozwój gospodarki, zmiany stylu życia ludności czy też wzrost świadomości i wymagań konsumentów wymuszają na przedsiębiorcach ciągły rozwój i poszukiwanie nowych rozwiązań skutecznej prezentacji i promocji produktów. Opakowanie postrzegane jest jako jeden $\mathrm{z}$ podstawowych elementów oddziaływania na rynek, promocji marki oraz aktywizacji sprzedaży. Dyferencjacja opakowań jest ściśle związana z dążeniem do wyróżnienia produktów na tle bogatej oferty rynkowej. Kreowanie unikatowości opakowań w dużej mierze opiera się na innowacyjnych projektach warstwy

1 Dr inż. Agnieszka Cholewa-Wójcik, Katedra Opakowalnictwa Towarów, Uniwersytet Ekonomiczny w Krakowie, Kraków, tel.: +48 122935 169, e-mail: cholewaa@uek.krakow.pl 
wizualnej opakowań. Atrakcyjna forma konstrukcyjna, dobór barw czy interesująca grafika przyciągają wzrok i zapadają w pamięci potencjalnym konsumentom. Opakowanie ma za zadanie stworzyć pożądany wizerunek produktu, który będzie wzbudzał zaufanie oraz przekona do zakupu. Opakowanie wpływa na identyfikowalność danego wyrobu z marką oraz poprzez wybrane elementy komunikacji wizualnej wspomaga proces przekazywania informacji między nadawcą komunikatu a jego potencjalnym odbiorcom. Stąd współczesne opakowanie traktowane jako narzędzie skutecznej komunikacji, źródło doznań i doświadczeń, za pomocą którego można skutecznie oddziaływać na odbiorcę komunikatu.

Celem pracy jest analiza wybranych elementów komunikacji wizualnej opakowań żeli pod prysznic dostępnych w ofercie rynkowej. Eksploracja uzyskanych wyników badań okulograficznych umożliwi wskazanie najbardziej efektywnych elementów komunikacji wizualnej opakowań. Natomiast wykorzystanie testu $\chi 2$ pozwoli na określenie zależności postrzegania graficznych i typograficznych elementów komunikacji opakowań od grup wiekowych badanych.

\section{ROLA OPAKOWANIA W KOMUNIKACJI WIZUALNEJ}

Komunikacja wizualna definiowana jest jako komunikacja za pomocą form obrazkowych. W formie wizualnej przekazywane są informacje pomiędzy nadawcą a potencjalnym odbiorcą komunikatu. Zasadniczo komunikacja wizualna bazuje na takich elementach wyrazu jak: ilustracja, fotografia, typografia, infografika czy animacja. Badania prowadzone przez m.in. przez U.R. Orth, K. Malkewitz ${ }^{2}$ D. Gelici-Zeko, R. Lutters, T. Klooster, P.Weijzen ${ }^{3}$, A. Cholewa-Wójcik, J. Świda ${ }^{4}$ dowodzą, że za pomocą obrazu, popartego tekstem można skuteczniej oddziaływać na odbiorcę komunikatu ${ }^{5}$.

Komunikacja wizualna znalazła swoje zastosowanie w nowoczesnym narzędziu zintegrowanego marketingu jakim jest opakowanie. Współcześnie opakowanie traktowane jest jako istotny nośnik zakodowanych komunikatów rynkowych. Spójny system wizualny opakowania może być jednym z ważniejszych elementów całościowej identyfikacji, który bezpośrednio przekłada się na sposób postrzegania produktu przez konsumenta i w efekcie może mieć decydujący wpływ na jego wybór. Poprzez oryginalność formy i treści przekazu można skutecznie oddziaływać na potencjalnego odbiorcę .

Kreowanie pozytywnych emocji i wrażeń produktu poprzez opakowanie realizowane jest poprzez jego warstwę wizualną. Korelacja cech i elementów opakowania tworzących wyobrażenie o zapakowanym produkcie określana jest mianem designu czyli tzw. języka

\footnotetext{
${ }^{2}$ U.R. Orth, K. Malkewitz, Holistic Package Design and Consumer Brand Impressions, Journal of Marketing 2008 , vol.72.

${ }^{3}$ D. Gelici-Zeko, R. Lutters, T. Klooster, P. Weijzen, Studying the Influence of Packaging Design on Consumer Perceptions (of Dairy Products) Using Categorizing and Perceptual Mapping, Packaging Technology and Science 2012, vol. 26, issue 4.

${ }^{4}$ A. Cholewa-Wójcik, J. Świda, Perceptions of packages through the prism placed on them graphic elements - analysis using eye-tracking method, Opakowanie 2015, $\mathrm{nr} 3$.

${ }^{6}$ M. Lisińska -Kuśnierz, M. Ucherek, Essence of Holistic angle on Development of Consumer Behaviour by Packaging, Towaroznawcze Problemy Jakości 2011, nr 4.

${ }^{7}$ A. Ankiel-Homa, Wartość komunikacyjna opakowań jednostkowych, PWE Poznań 2012.

${ }^{8}$ V.Butkevivience, J. Stavinskiene, A. Rutelione, Impact of consumer package communication on consumer decision making process, Engineering Economics 2008, nr 1.
} 
opakowania $^{7}$. Według opracowanego przez Butkevicience, Stavinskiene i Rutelione ${ }^{8}$ Modelu Komunikacji Opakowania, design opakowania obejmuje zarówno wizualne i werbalne elementy, jak również cechy opakowania rozumiane jako sposób jego postrzegania.

Do elementów wizualnych opakowań będących częścią systemu identyfikacji wizualnej zalicza się: kształt opakowania, wzornictwo, typografię, kolorystykę opakowania oraz logo/logotyp. Z kolei fundamentem werbalnym designu opakowania są treści informacyjne przekazywane poprzez fenomowo-wyrazowe i ideograficzne znaki językowe. Natomiast postrzeganie opakowań polega na percypowaniu elementów składowych i ich interpretacji oraz nadaniu im odpowiedniego znaczeni ${ }^{9}$

Wyodrębnione elementy identyfikacji wizualnej powinny być nieskomplikowane, łatwe do zapamiętania oraz powinny być zgodne z misją i wartościami firmy, a także pełnić funkcję dyferencjacyjną. Design opakowania obejmuje więc całościową kompozycję cech i elementów opakowań, która dostarcza konsumentowi użytkowych, hedonistycznych i semiotycznych korzyści ${ }^{10}$.

Korzyści użytkowe analizowane w kontekście funkcjonalności odnoszą się do wypełnienia przez opakowanie funkcji użyteczności. Hedonistyczne elementy odnoszą się z kolei do zdolności opakowania do zaspokojenia oczekiwań sensorycznych i czerpania pozytywnych doświadczeń w kontakcie z zapakowanym produktem. Natomiast wartość semiotyczna przejawia się $\mathrm{W}$ racjonalności i sprawności $\mathrm{W}$ aktach poznania $\mathrm{i}$ komunikowania ${ }^{11}$.

\section{PRZEDMIOT I METODYKA BADAŃ}

Przedmiot badań stanowiły opakowania żeli pod prysznic dla kobiet dostępne w ofercie rynkowej. Do badań wybrano opakowania o różnorodnej warstwie wizualnej (różniące się między sobą m.in. kształtem, barwą, grafiką, ilością zamieszczonych informacji tekstowych oraz wielkością i rodzajem czcionki. Opakowania te ponadto pochodziły od różnych producentów, tak więc były również zróżnicowane pod względem logo/logotypu. Przedmiot badań zaprezentowano na rys. 1.

${ }^{9}$ S. T. Wei, L. C. Ou, M. R, Luo \& J. B. Hutchings, Package design: Colour harmony and consumer expectations, International Journal of Design 2014, $\mathrm{nr} 8$ (1).

${ }^{10}$ P.H. Bloch, Product design and marketing: reflaction after fifteen years, Journal of Product Innovation Management 2011, nr 28.

${ }^{11}$ E. Jerzyk, Design opakowania i jego elementy $w$ procesie podejmowania decyzji zakupowych, Marketing i Rynek 2014, nr 4. 
Rys. 1. Opakowania żeli pod prysznic
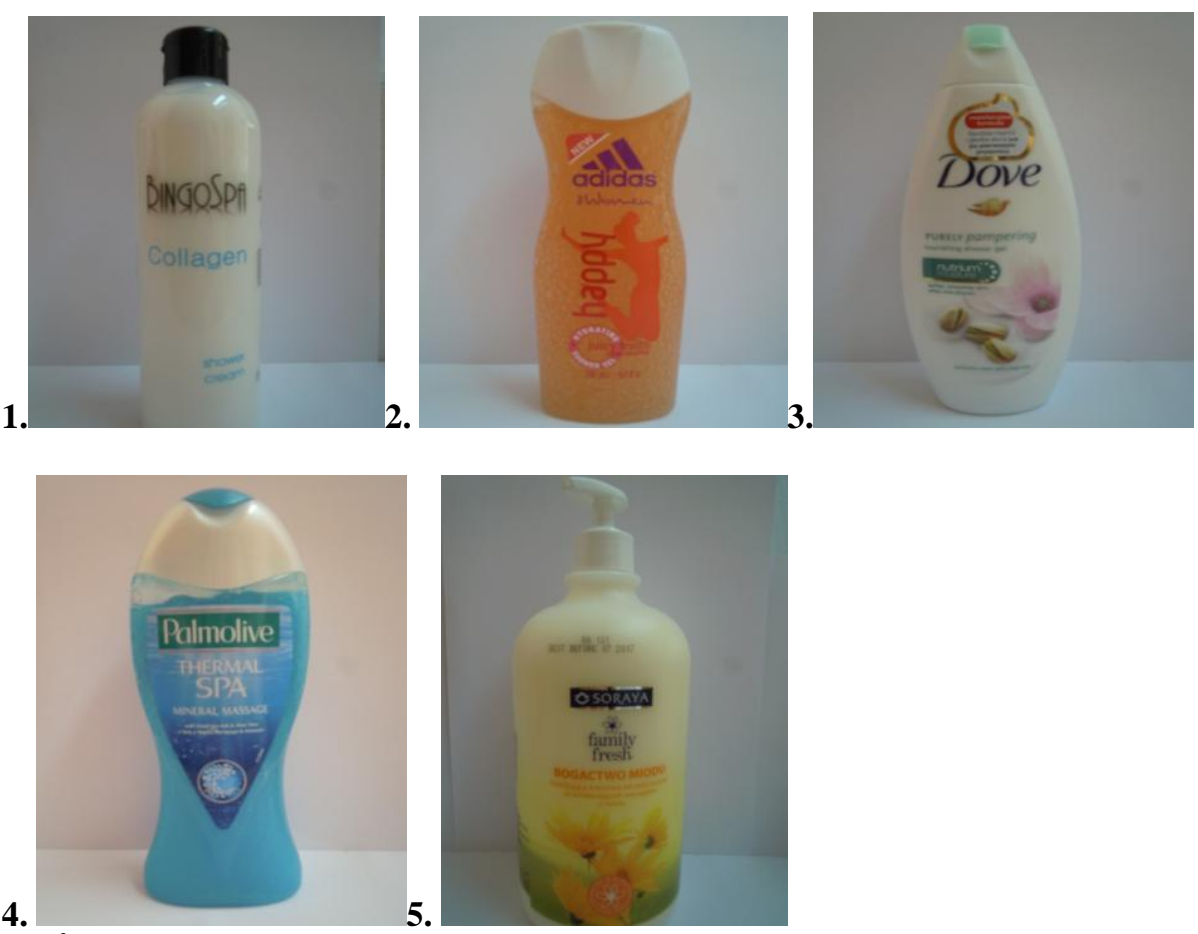

Źródło: Fot. A. Cholewa-Wójcik.

Do badania elementów warstwy wizualnej wyżej zaprezentowanych opakowań żeli pod prysznic dla kobiet zastosowano metodę eye-tracking polegającą na śledzeniu ruchów gałek ocznych uczestników badania przy jednoczesnej możliwości analizy sakad ${ }^{12} \mathrm{i}$ fiksacji ${ }^{13}$. Metoda ta traktowana jest zarówno jako badanie jakościowe i ilościowe. $\mathrm{Z}$ uwagi na pomiarowy i fizjologiczny charakter badania, bazującego na pomiarze pracy narządu wzroku, uzyskano możliwość otrzymania reprezentatywne danych ilościowych. Ponadto otrzymano również mierzalny materiał jakościowy, będący punktem wyjścia do innego typu badań np. deklaratywnych. Metoda ta pozwala uzupełnić badania użyteczności o wiedzę obiektywną, uzyskaną w oparciu o analizę rzeczywistych zachowań osób badanych a nie tylko ich subiektywnych opinii. Ponadto metoda ta umożliwia określenie sposobu postrzegania przez konsumentów poszczególne elementy warstwy wizualnej opakowania a więc umożliwia poznanie percepcji wzrokowej potencjalnych konsumentów. Dzięki temu można się dowiedzieć m.in. na jakich

\footnotetext{
${ }^{12}$ Sakady- intensywne ruchy gałki ocznej, polegające na bardzo szybkim przemieszczaniu punktu koncentracji wzroku z jednego miejsca na inne.

${ }^{13}$ Fiksacje- relatywnie stała pozycja gałki ocznej, w trakcie której następują niewielkie drgania. Przyjmuje się, że w trakcie fiksacji następuje proces poznawczy, tzn. informacje docierają do mózgu i są świadomie przetwarzane.
} 
obszarach opakowania skupia się wzrok konsumenta a które są przez niego całkowicie pomijane ${ }^{14,15}$.

Badania przeprowadzono $\mathrm{z}$ wykorzystaniem eyetrackera Tobii X2-30 z oprogramowaniem Tobii Studio Version 3.2. W badaniu, przeprowadzonym w 2015 roku, udział wzięło 45 kobiet w następujących grupach wiekowych: od 20-35 lat, 36-50 lat oraz powyżej 50 lat. Zakres przeprowadzonych badań dotyczył określenia obszarów warstwy wizualnej opakowań żeli pod prysznic na których skupiał się wzrok konsumentów oraz określenia ważności tych elementów na podstawie bazowych miar eyetrackingowych takich jak: ścieżka skanowania, liczba fiksacji oraz całkowity czas trwania fiksacji.

Uzyskane wyniki badań przedstawiono w formie map cieplnych, które są rozkładem uwagi kierowanej na badany obszar zainteresowania, z możliwością wyodrębnienia elementów zauważonych i pominiętych podczas skanowania wzroku. Mapy cieplne przy pomocy barw pokazują uśredniony obraz obszarów opakowania, na których badani skupiali swój wzrok. Miejsca gdzie wzrok skupiał się najczęściej oznaczone zostały barwą czerwoną. Obszary gdzie dochodziło do mniejszej liczby spojrzeń oznaczane zostały na żółto, natomiast miejsca gdzie było ich najmniej na zielono. Barwy mapy prezentują łączną liczbę i czas fiksacji badanych czyli punktów, w których wzrok się zatrzymał w danym obszarze obrazu. Ponadto do analizy uzyskanych wyników badań zastosowano także ścieżkę skanowania wzroku, wskazującą kolejność aktywności wzrokowej badanych w ramach wytyczonych obszarów zainteresowania (AOI).

\section{ANALIZA WYNIKÓW BADAŃ WŁASNYCH}

Prezentowane w literaturze wyniki badań prowadzone m.in. przez J. Clement ${ }^{16}, \mathrm{~V}$. Butkevicience, J. Stavinskiene, A. Rutelione ${ }^{17}$, L. Garber, E. Hyatt, U. Boyna ${ }^{18}$, M. I. Suero, P.J. Parolo i A. L. Perez ${ }^{19}$, A. Cholewa-Wójcik i J. Świda ${ }^{4}$, oraz A. CholewaWójcik i A. Kawecka ${ }^{20}$ dowodzą, że spośród elementów tworzących warstwę wizualną opakowań istotną rolę z punku widzenia efektywności opakowania i spełniania jego funkcji marketingowej odgrywają elementy wizualne, werbalne oraz cechy rozumiany jako sposób postrzegania opakowania.

\footnotetext{
${ }^{14}$ J.R. Bergstromm, A.J. Schall, Eye tracking in user experience design, Elsevier, USA 2014.

${ }^{15}$ A. Duchowski, Eye Tracking Methodology, Theory and Practice, Secon Edition, Sprnger, London 2007.

${ }^{16} \mathrm{~J}$. Clement, Visual influence on in-store buying decision: an eye-track experiment on visual influence of packaging design, Journal of Marketing Management 2007, vol. 23, nr 9-10.

${ }^{8}$ V.Butkevivience, J. Stavinskiene, A. Rutelione, op. cit..

${ }^{18}$ L. Garber, E. Hyat, U. Boyna, The effect of package shape on apparent volume: an exploratory study with implication for package design, Journal of Marketing Theory and Practice 2009, vol. 17.

${ }^{18}$ M.I. Suero, P.J. Pardo, A.L. Perez, Individual Differences in Colour Vision, w: Color Perception: Physiology, Processes and Analysis, Neuroscience Research Progress Series, ed . by D. Skusevich and P. Matikas, Nova Science Publishers, New York 2010

${ }^{19}$ A. Cholewa-Wójcik, A. Kawecka, The influence of effectiveness of packaging elements on consumers' preferences with the use of marketing eye-tracking technique, Modern Management Review 2015 (1), vol. XX, 22.
} 
W celu zidentyfikowania opakowań zwracających swoją warstwą wizualną największą uwagę potencjalnych konsumentów dokonano analizy swobodnego patrzenia badanych. Wyniki analizy percepcji wzrokowej $\mathrm{z}$ wykorzystaniem wybranych miar eyetrackingowych zaprezentowano w tabeli 1.

Tabela 1. Wyniki analizy percepcji wzrokowej $\mathrm{z}$ wykorzystaniem wybranych miar eye-trackingowych

\begin{tabular}{|c||c||c|c|}
\hline \multirow{2}{*}{$\begin{array}{c}\text { Analizowane } \\
\text { opakowania żeli } \\
\text { pod prysznic }\end{array}$} & \multicolumn{3}{|c|}{ Miary eye-trackingowe } \\
\cline { 2 - 4 } & Liczba fiksacji & $\begin{array}{c}\text { Czas do pierwszej } \\
\text { fiksacji [s] }\end{array}$ & $\begin{array}{c}\text { Czas trwania fiksacji } \\
{[\mathbf{s}]}\end{array}$ \\
\hline \hline 1 & 12,13 & 0,02 & 3,90 \\
\hline \hline 2 & 12,40 & 0,25 & 3,95 \\
\hline \hline 3 & 12,60 & 0,01 & 4,06 \\
\hline \hline 4 & 12,53 & 0,03 & 3,97 \\
\hline \hline 5 & 12,53 & 0,01 & 3,94 \\
\hline
\end{tabular}

Źródło: badania własne.

Analiza wyników otrzymanych z testu swobodnego patrzenia wykazała, że wszystkie badane opakowania wzbudzają zainteresowanie potencjalnych nabywców. Suma wszystkich fiksacji kształtowała się w nieznacznie różniącym się przedziale od 12,13 do 12,60. W przypadku analizowanych opakowań żeli pod prysznic, największe zainteresowanie wzbudziło opakowanie $\mathrm{nr} 3$ - „Dove”, dla którego odnotowano największą liczbę fiksacji $(12,60)$. Dla badanych to opakowanie było najbardziej zauważalne w procesie skanowania wzrokiem. Najmniejszą liczbę fiksacji odnotowano natomiast dla opakowania nr 1- „Bingo Spa” $(12,13)$.

Analizując wyniki badań zdolności opakowań do skupiania uwagi odnotowano bardzo niskie tzw. czasy do pierwszej fiksacji ${ }^{21}$ wynoszące od 0,01 do $0,03 \mathrm{~s}$. Wyjątkiem było opakowanie nr 2-,,Adidas”, które uzuskało stosunkowo bardzo wysoki czas do pierwszej fiksacji wynoszący 0,25 s. Najniższy czas do pierwszej fiksacji odnotowano dla opakowań nr 3 oraz 5. Wyniki eye-trackingowych statystyk opisowych potwierdzają, że opakowania te nie tylko wzbudziły największe zainteresowanie badanych ale także zostały najszybciej dostrzeżone.

Uzupełnieniem analiz percepcji opakowań była interpretacja wyników czasu trwania fiksacji w określonym obszarze badania. Czas trwania fiksacji traktowany jest jako miara narzuconych wymagań poznawczego przetworzenia nagromadzonych informacji. W przypadku analizowanych opakowań żeli pod prysznic czas trwania fiksacji kształtował się w przedziale od 3,90 do 4,06 s. Najczęściej oglądane było opakowanie nr 3 .

${ }^{21}$ Czas do pierwszej fiksacji: czas w sekundach od momentu pokazania bodźca do pierwszego zapisu w AOI. 
Najkrótszy czas oglądania odnotowano dla opakowania nr 1. Natomiast opakowanie nr 2 i 5 posiadało porównywalny czas oglądania w procesie skanowania wzrokiem.

W celu wyodrębnienia elementów warstwy wizualnej opakowań napojów energetycznych, które wzbudzają największe zainteresowanie potencjalnych konsumentów dokonano analizy percepcji osób na podstawie analizy map cieplnych. Uzyskane wyniki badań eye-trackingowych zaprezentowano na rys.2.

Rys. 2. Mapy cieplne analizowanych opakowań żeli pod prysznic

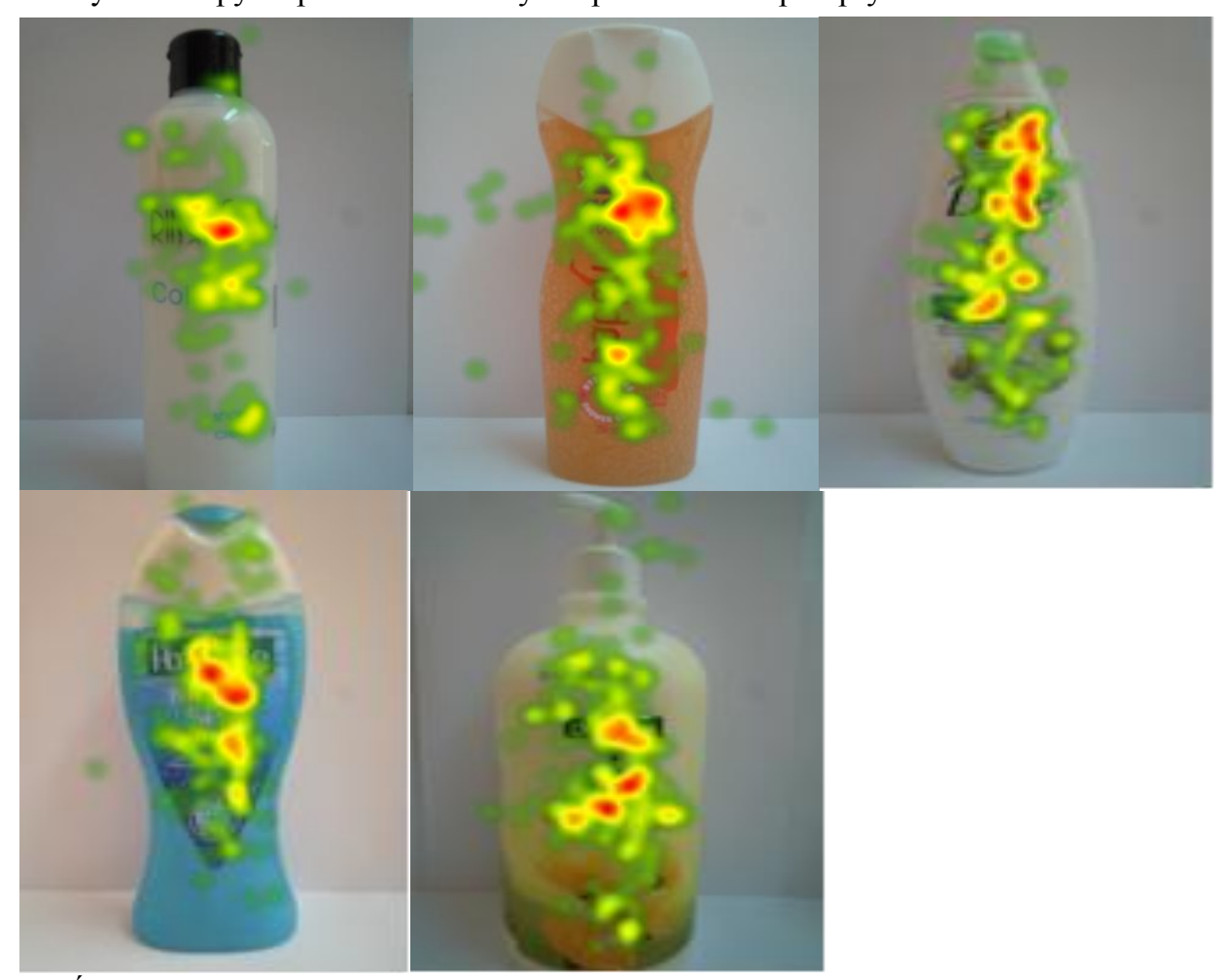

Źródło: badania własne.

Analiza zróżnicowania sumarycznego natężenia uwagi poprzez wykorzystanie barw pozwoliła na określenie stopnia skupienia uwagi na opakowaniu od największego stopnia skupienia uwagi (oznaczonego kolorem czerwonym), poprzez średni (oznaczony kolorem żółtym) aż do małego (oznaczonego kolorem zielonym). Eksploracja aktywności wzrokowej badanych na podstawie uśrednionego obrazu obszarów opakowania wykazała, że w przypadku wszystkich analizowanych opakowań żeli pod prysznic w największym stopniu badani skupiali swój wzrok na elementach opakowania posiadających wysoce perswazyjny charakter. Elementy te mogą istotnie wpływać na potencjalnego nabywcę poprzez wywieranie na nim określonych wrażeń i tworzenia zamierzonej atmosfery (np. 
wrażenia wysokiej jakości, prestiżu, dobrobytu, luksusu) co potwierdzają wyniki badań prowadzonych przez Wright, Ward ${ }^{22}$.

W celu określenia kolejności postrzegania obszarów czyli tzw. kierunku skanowania wzrokiem, zaprezentowane mapy cieplne opakowań żeli pod prysznic badań wzbogacono dodatkowo interpretacją ścieżki skanowania, które przedstawiono na rys. 3 .

Rys. 3. Ścieżki skanowania obszarów skupień wzroku analizowanych opakowań żeli pod prysznic

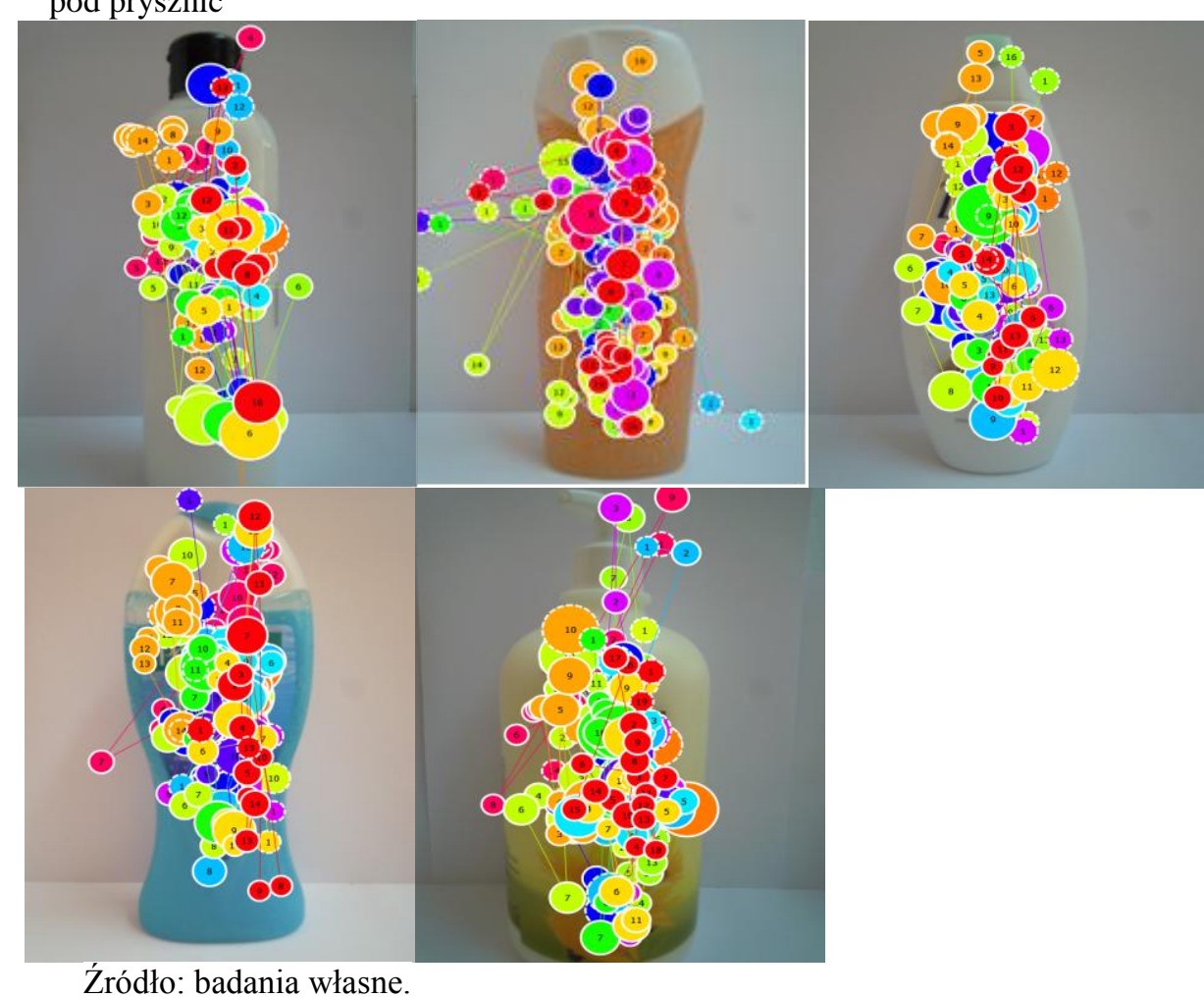

Analiza tworzonych na ścieżce skanowania obszarów skupień wzroku określanych mianem gaze ploty potwierdziła, że w przypadku wszystkich analizowanych opakowań żeli pod prysznic sugestywne elementy opakowania wywołują tzw. efekt pendulum. Na podstawie analizy ścieżki skanowania obszarów zainteresowania wskazano, że elementem skupiającym znaczącą większość zasobów uwag badanych było logo/logotyp. Drugim w kolejności elementem zwracającym uwagę badanych były dodatkowe informacje tekstowe umieszczone na opakowaniach. Natomiast elementem, na który badani zwracali najmniejsza uwagę były elementy graficzne.

W celu potwierdzenia hierarchii elementów warstwy wizualnej opakowań żeli stworzonej na podstawie analizy ścieżki skanowania wzroku, podjęto próbę określenia

${ }^{22}$ R.D. Wright., L.M. Ward., Orienting of Attention, Oxford University Press, New York 2008. 
istotności elementów warstwy wizualnej opakowań żeli pod prysznic w oparciu o liczbę oraz całkowity czas fiksacji. Uzyskane wyniki badań eye-trackingowych uwzględniających wybrane parametry statystyki opisowej zestawiono w tab.2.

Analiza wyników badań eye-trackingowych zaprezentowanych w tabeli 2, wykazała, że spośród analizowanych obszarów opakowań żeli pod prysznic, elementem skupiającym wzrok w największym stopniu jest logo/logotyp. Dla tego elementu opakowań odnotowano największą sumę fiksacji (252 fiksacje). Spośród analizowanych elementów opakowań żeli pod prysznic całkowity czas trwania fiksacji kształtował się w przedziale od 1,27 do 2,51 sekundy. Z kolei łączna liczba tzw. wizyt analizowanych opakowań kształtowała się na poziomie od 22-44.

Biorąc pod uwagę kryterium sumy wszystkich fiksacji, drugim analizowanym obszarem opakowań żeli pod prysznic, który skupiał uwagę badanych były dodatkowe informacje tekstowe umieszczone na opakowaniach. Łączna ilość fiksacji dla tego obszaru wynosiła 195. Przy czym największą liczbę fiksacji odnotowano dla opakowania nr 5 (52 fiksacje). Natomiast najmniejszą liczbę fiksacji uzyskało opakowanie nr 3 (28 fiksacji). Całkowity czas trwania fiksacji dla analizowanych informacji dodatkowych zamieszczonych na opakowaniach wynosił od 1,67 do 5,95 sekundy. Przy czym najkrótszy czas trwania fiksacji (1,67sekundy) uzyskano dla opakowania $\mathrm{nr} 4$. Natomiast najdłuższy czas trwania fiksacji (5,95 sekundy) uzyskało opakowanie $\mathrm{nr} 5$, co świadczy, że analiza wzrokowa zamieszczonych dodatkowych informacji tekstowych charakteryzowała się znacznie większą dogłębnością przetwarzania danych znajdujących się aktualnie w polu wzorkowym. Dla analizowanego elementu w postaci dodatkowych informacji tekstowych zamieszczonych na opakowaniach żeli pod prysznic odnotowano rozpiętość wartości w przedziale całkowitego czasu trwania fiksacji. Zidentyfikowana rozpiętość czasu skupienia uwagi badanych na danym obszarze opakowania może wynikać z różnic wzorniczych występujących w poszczególnych elementach warstwy wizualnej takich jak: grafika, wielkość i rodzaj czcionki, oraz barwa, co znajduje potwierdzenie w badaniach prowadzonych m.in. przez oraz D.Gelici-Zeko, R. Lutters, T. Klooster, P. Weijzen. Zidentyfikowane różnice w postrzeganiu analizowanych opakowań żeli pod prysznic mogą wynikać także z wieku badanych. Badania prowadzone przez J.B. Taylor'a oraz L. Brizendine wykazały bowiem, iż preferencje poszczególnych grup wiekowych konsumentów przekładają się na specyficzny sposób dekodowania i przechowywania informacji. 
Tabela 2. Wyniki badań eye-trackingowych wybranych elementów opakowań żeli pod prysznic

\begin{tabular}{|c|c|c|c|c|}
\hline \multirow{3}{*}{$\begin{array}{l}\text { Analizowane } \\
\text { opakowania } \\
\text { pod prysznic }\end{array}$} & \multirow[t]{3}{*}{ Pomiar } & \multicolumn{3}{|c|}{ Obszar opakowania } \\
\hline & & Logo/Logotyp & $\begin{array}{c}\text { Dodatkowe } \\
\text { informacje } \\
\text { tekstowe }\end{array}$ & $\begin{array}{l}\text { Elementy } \\
\text { graficzne }\end{array}$ \\
\hline & & \multicolumn{3}{|c|}{$\begin{array}{c}\text { Statystyka opisowa } \\
\text { Suma } \\
\text { Stdev } \\
\end{array}$} \\
\hline \multirow[t]{3}{*}{1} & Liczba fiksacji & $\begin{array}{c}77,00 \\
2,29 \\
\end{array}$ & $\begin{array}{c}39,00 \\
1,58 \\
\end{array}$ & - \\
\hline & Czas fiksacji & $\begin{array}{l}2,31 \\
0,82\end{array}$ & $\begin{array}{l}3,28 \\
0,36\end{array}$ & $\begin{array}{l}- \\
-\end{array}$ \\
\hline & Liczba wizyt & $\begin{array}{c}41,00 \\
0,88\end{array}$ & $\begin{array}{c}25,00 \\
0,76 \\
\end{array}$ & - \\
\hline \multirow[t]{3}{*}{2} & Liczba fiksacji & $\begin{array}{c}58,00 \\
2,44\end{array}$ & $\begin{array}{c}30,00 \\
3,0\end{array}$ & $\begin{array}{c}43,00 \\
1,9\end{array}$ \\
\hline & Czas fiksacji & $\begin{array}{l}2,48 \\
0,92\end{array}$ & $\begin{array}{l}4,83 \\
0,94\end{array}$ & $\begin{array}{l}2,36 \\
0,51\end{array}$ \\
\hline & Liczba wizyt & $\begin{array}{c}34,00 \\
1,02 \\
\end{array}$ & $\begin{array}{c}15,00 \\
0,87 \\
\end{array}$ & $\begin{array}{c}28,00 \\
1,11 \\
\end{array}$ \\
\hline \multirow[t]{3}{*}{3} & Liczba fiksacji & $\begin{array}{c}44,00 \\
2,63 \\
\end{array}$ & $\begin{array}{c}28,00 \\
1,44 \\
\end{array}$ & $\begin{array}{c}26,00 \\
1,71 \\
\end{array}$ \\
\hline & Czas fiksacji & $\begin{array}{l}2,51 \\
0,72 \\
\end{array}$ & $\begin{array}{l}3,71 \\
0,51 \\
\end{array}$ & $\begin{array}{l}2,11 \\
0,56 \\
\end{array}$ \\
\hline & Liczba wizyt & $\begin{array}{c}30,00 \\
0,95\end{array}$ & $\begin{array}{c}20,00 \\
0,98\end{array}$ & $\begin{array}{c}16,00 \\
0,70\end{array}$ \\
\hline \multirow[t]{3}{*}{4} & Liczba fiksacji & $\begin{array}{c}43,00 \\
2,69 \\
\end{array}$ & $\begin{array}{c}46,00 \\
1,86 \\
\end{array}$ & $\begin{array}{c}21,00 \\
1,37 \\
\end{array}$ \\
\hline & Czas fiksacji & $\begin{array}{l}1,27 \\
1,06 \\
\end{array}$ & $\begin{array}{l}1,67 \\
0,67 \\
\end{array}$ & $\begin{array}{l}1,10 \\
0,34 \\
\end{array}$ \\
\hline & Liczba wizyt & $\begin{array}{c}26,00 \\
1,00\end{array}$ & $\begin{array}{c}34,00 \\
1,02\end{array}$ & $\begin{array}{c}14,00 \\
0,70\end{array}$ \\
\hline \multirow[t]{3}{*}{5} & Liczba fiksacji & $\begin{array}{c}30,00 \\
1,44 \\
\end{array}$ & $\begin{array}{c}52,00 \\
2,15 \\
\end{array}$ & $\begin{array}{c}22,00 \\
1,33 \\
\end{array}$ \\
\hline & Czas fiksacji & $\begin{array}{l}2,44 \\
0,68 \\
\end{array}$ & $\begin{array}{l}5,95 \\
0,88 \\
\end{array}$ & $\begin{array}{l}3,03 \\
0,00 \\
\end{array}$ \\
\hline & Liczba wizyt & $\begin{array}{c}22,00 \\
0,69 \\
\end{array}$ & $\begin{array}{c}25,00 \\
0,58 \\
\end{array}$ & $\begin{array}{c}15,00 \\
0,87 \\
\end{array}$ \\
\hline
\end{tabular}

Źródło: badania własne.

Ponadto analiza zaprezentowanych w tabeli 2 wyników wykazała, że w porównaniu z logo/logotypem oraz dodatkowymi informacjami tekstowymi umieszczanymi na opakowaniach, elementy graficzne przyciągają najmniejszą uwagę badanych. Dla tego elementu warstwy wizualnej w przypadku opakowań żeli pod prysznic odnotowano 
łączną liczbę fiksacji wynoszącą 112, przy całkowitym czasie trwania fiksacji od 1,1 do 3,03 sekundy.

Analizowane wybrane elementy komunikacji wizualnej opakowań w oparciu o priorytetowe miary eyetrackingowe, uzupełniono analizą wskaźnika Stdev jako reprezentanta statystyki opisowej. Wskaźnik StDev jest statystyczną miarą zmienności i pokazuje, jak bardzo analizowane miary odbiegają od wartości średniej. W przypadku analizy wartości współczynnika wspomagającego Stdev dla liczby fiksacji w analizowanych obszarach zainteresowania uzyskano stosunkowo nieduże rozbieżności danych: 1,33-1,9 (dla elementów graficznych), 1,44-2,69 (dla logo/logotypu) oraz 1,583,0 (dla tekstowych informacji dodatkowych). Natomiast znacznie mniejsze rozbieżności odnotowano w przypadku wartości współczynnika Stdev dla wyznaczonych czasów fiksacji. Stosunkowo niedużą zmiennością charakteryzowały się czasy fiksacji wyznaczone dla elementów graficznych $(0,00-0,51)$ oraz nazw produktów $(0,36-0,94)$ oraz dla logo/logotypu analizowanych opakowań $(0,68-1,06)$.

Uzyskane wyniki badań okulograficznych stanowiły podstawę do weryfikacji możliwości wykorzystania nieparametrycznego testu niezależności poprzez testowanie hipotezy zerowej niezależności wieku respondentów i średniej liczby fiksacji wybranych (graficznych i typograficznych) elementów komunikacji wizualnej analizowanych opakowań. Uzyskane wyniki testu $\chi 2$ zaprezentowano w tabeli 3.

Tabela 3. Analiza zależności liczby fiksacji wybranych elementów komunikacji wizualnej opakowań od grup wiekowych respondentów

\begin{tabular}{|c|c|c|c|c|}
\hline \multirow[t]{2}{*}{ Miary statystyki opisowej } & \multicolumn{3}{|c|}{ Grupy wiekowe respondentów } & \multirow{2}{*}{$\begin{array}{c}\text { Wartość testu } \chi^{2} \\
p\end{array}$} \\
\hline & $20-35$ & $36-50$ & 50+ & \\
\hline $\begin{array}{l}\text { Srednia liczba fiksacji dla } \\
\text { logo/logotypu }\end{array}$ & 103 & 87 & 62 & 0,000488 \\
\hline $\begin{array}{l}\text { Średnia liczba fiksacji dla } \\
\text { dodatkowych informacji } \\
\text { tekstowych }\end{array}$ & 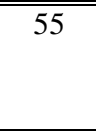 & 81 & 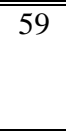 & 0,010856 \\
\hline $\begin{array}{l}\text { Średnia liczba fiksacji dla } \\
\text { elementów graficznych }\end{array}$ & 43 & 29 & 40 & 0,112699 \\
\hline
\end{tabular}

Źródło: badania własne.

Eksploracja danych zawartych w tabeli 2 wykazała, że analizowana zależność wieku i średniej liczby fiksacji dla logo/logotypu, jak również średniej liczby fiksacji dla dodatkowych informacji tekstowych jest istotna statystycznie gdyż wartość tego prawdopodobieństwa jest mniejsza niż 0,05 . Pomiędzy analizowanymi zmiennymi istnieje związek, stąd zasadność odrzucenia hipotezy zerowej.

Natomiast w przypadku analizy zależności wieku respondentów i liczby fiksacji dla elementów graficznych uzyskano wartość $\mathrm{p}>0,005$. W tym przypadku nie istnieje związek 
między zmiennymi i różnica nie jest istotna statystycznie. Stąd nie ma podstaw do odrzucania hipotezy zerowej.

\section{PODSUMOWANIE}

Współczesne opakowanie to jedno $\mathrm{z}$ najskuteczniejszych narzędzi komunikacji marketingowej oraz stymulator decyzji zakupowych. Opakowanie jednostkowe traktowane jest jako celowy komunikat, który ma wpłynąć na sferę kognitywną (postrzeganie produktu) oraz afektywną (postawa wobec produktu). Dzięki właściwej kompozycji elementów i cech opakowanie może wpływać na jego zauważenie, kreować wyobrażenie o poziomie jakości produktów, oraz sugerować określone korzyści. Efektywne opakowanie dostarcza potencjalnemu konsumentowi zarówno użytkowych, hedonistycznych, jak i semiotyczne korzyści.

Analiza uzyskanych wyników badań pozwoliła na poznanie i wzbogacenie wiedzy dotyczącej percepcji wzrokowej potencjalnych konsumentów. Ponadto szczegółowa eksplikacja aktywności wzrokowej badanych wzbogacona o interpretację liczby oraz całkowitego czasu fiksacji pozwoliła na określenie obszarów skupiających największą uwagę potencjalnych konsumentów.

Wyniki badań eyetrackingowych wykazały, że spośród analizowanych elementów opakowań żeli pod prysznic, dominującym elementem skupiającym znaczące zasoby uwagi konsumentów jest logo/logotyp. Kolejnym istotnym elementem warstwy wizualnej opakowań, który również posiada zdolność przyciągania i koncentracji uwagi są informacje tekstowe umieszczone na frontowej części opakowania. W przypadku opakowań żeli pod prysznic, elementem, który w najmniejszym stopniu ogniskował uwagę badanych były elementy graficzne. Uzyskane wyniki przeprowadzonych badań eye-trackingowych wykorzystano ponadto do weryfikacji możliwości zastosowania nieparametryczngo testu niezależności pozwalającego na weryfikację postawionej hipotezy zerowej mówiącej o niezależności wieku respondentów i średniej liczby fiksacji graficznych i typograficznych elementów komunikacji wizualnej analizowanych opakowań. Zastosowanie testu $\chi^{2}$ pozwoliło na wyodrębnienie logo/logotypu oraz informacji tekstowych, jako tych elementów komunikacji warstwy wizualnej opakowań żeli pod prysznic, które ściśle korelują z wiekiem badanych.

Reasumując podjęte rozważania można stwierdzić, że pomimo wskazanej hierarchii elementów warstwy wizualnej opakowań żeli pod prysznic z punktu widzenia możliwości przyciągania i skupiania uwagi potencjalnych konsumentów, należy mieć świadomość, iż postrzeganie opakowań i zamieszczonych na nich elementów jest wypadkową wielu czynników. Preferencje potencjalnego konsumenta są związane z korelacją aspektów dotyczących realizacji potrzeb w zakresie opakowań. Ponadto uzależnione są od czynników socjologicznych oraz indywidualnych predylekcji konsumentów.

The publication was funded by appropriations of the Faculty of Commodity Science Cracow University of Economics, a grant for the maintenance of the research potential. 


\section{BIBLIOGRAFIA}

[1] Ankiel-Homma M., Wartość komunikacyjna opakowań jednostkowych, PWE Poznań 2012.

[2] Ankiel-Homa M., Czaja-Jagielska N., Malinowska P., Opakowania kosmetyków-aspekty towaroznawcze $i$ marketingowe, IBRKK, Warszawa 2014.

[3] Bergstromm J.R., Schall A.J., Eye tracking in user experience design, Elsevier, USA 2014.

[4] Bloch P.H., Product design and marketing: reflaction after fifteen years, Journal of Product Innovation Management 2011, nr 28.

[5] Butkevivience V., Stavinskiene J., Rutelione A., Impact of consumer package communication on consumer decision making process, Engineering Economics 2008, nr 1.

[6] Cholewa-Wójcik A., Kawecka A., The influence of effectiveness of packaging elements on consumers' preferences with the use of marketing eye-tracking technique, Modern Management Review 2015 (1), vol. XX, 22.

[7] Cholewa-Wójcik A., Świda J., Perceptions of packages through the prism placed on them graphic elements - analysis using eye-tracking method, Opakowanie 2015, nr 3,

[8] Clement J., Visual influence on in-store buying decision: an eye-track experiment on visual influence of packaging design, Journal of Marketing Management 2007, vol. 23, nr 9-10.

[9] Duchowski A., Eye Tracking Methodology, Theory and Practice, Second Edition, Sprnger, London 2007.

[10] Garber L., Hyat E., Boyna U., The effect of package shape on apparent volume: an exploratory study with implication for package design, Journal of Marketing Theory and Practice 2009, vol. 17.

[11] Gelici-Zeko D., Lutters R., Klooster T., Weijzen P., Studying the Influence of Packaging Design on Consumer Perceptions (of Dairy Products) Using Categorizing and Perceptual Mapping, Packaging Technology and Science 2012, vol. 26, issue 4.

[12] Jerzyk E., Design opakowania i jego elementy $w$ procesie podejmowania decyzji zakupowych, Marketing i Rynek 2014, nr 4.

[13] Lisińska-Kuśnierz M., Ucherek M., Essence of Holistic angle on Development of Consumer Behaviour by Packaging, Towaroznawcze Problemy Jakości 2011, nr 4.

[14] Orth U.R., Malkewitz K., Holistic Package Design and Consumer Brand Impressions, Journal of Marketing 2008 , vol.72.

[15] Silayoi P., Speece M., 2007, Importance of packaging attributes: a conjoint analysis approach, European Journal of Marketing 2007, 41(11/12).

[16] Suero M.I., Pardo P.J., Perez A.L., Individual Differences in Colour Vision, w: Color Perception: Physiology, Processes and Analysis, Neuroscience Research Progress Series, ed . by D. Skusevich and P. Matikas, Nova Science Publishers, New York 2010.

[17] Strongman K.T., Psychology of Emotion, Fifth edition, Wiley, England 2003. 
[18] Wei S. T., Ou L. C., Luo M. R \& Hutchings J. B., Package design: Colour harmony and consumer expectations, International Journal of Design 2014, nr $8(1)$.

[19] Wright R.D., Ward L.M., Orienting of Attention, Oxford University Press, New York 2008

\section{VERIFICATION OF THE POSSIBILITY OF USE NONPARAMETRIC TEST OF INDEPENDENCE PERCEPTION FOR ANALYSIS OF SELECTED ELEMENTS OF VISUAL COMMUNICATION PACKAGE}

The packaging is a modern tool of integrated marketing and one of the most important product attributes affect consumer purchasing preferences. The packaging is designed to create the desired image of the product, which will be inspired confidence and convince to buy. It affects the traceability of the product with the brand, differentiates the same articles of several manufacturers, promotes communication as well as educates. As a medium of communication package acts as an element that identifies the product with the brand. Thus, today the packaging is treated as a tool for effective communication with potential consumers. Moreover, the package is treated as a major media market coded messages. Coherent system of visual package may be one of the most important elements of a comprehensive identification, which directly translates into the perception of the consumer, and as a result may have a decisive influence on his choice. Through the originality of the form and content of communication can effectively interact with the potential recipient. The aim of the study is to analyze selected elements of visual communication packages using the test eye tracking. Due to the nature of the test and physiological studies using EyeTracker Tobii X2-30, based on the measurement of the work of the eye, gave the opportunity to receive a representative quantitative data. Furthermore, a well measurable qualitative material, which is the starting point for other types of research such declarative. Exploration of research results allows for identification of the most effective elements of visual communication packages. The use of the $\chi^{2}$ test will determine the relation of perception of graphic and typographic communication elements of packaging from age groups surveyed. Keywords: visual communication packages, eye-tracking, nonparametric test of independence.

DOI:10.7862/rz.2016.hss.38

Przesłano do redakcji: styczeń 2016

Przyjęto do druku: wrzesień 2016 